Универзитет уметности у Београду, Факултет драмских уметности - Менаџмент и продукција позоришта, радија и културе, Београд

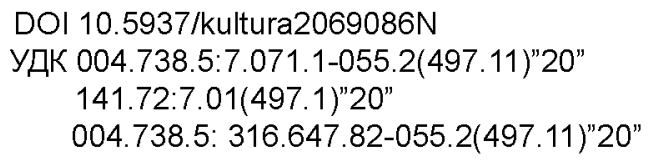

оригиналан научни рад

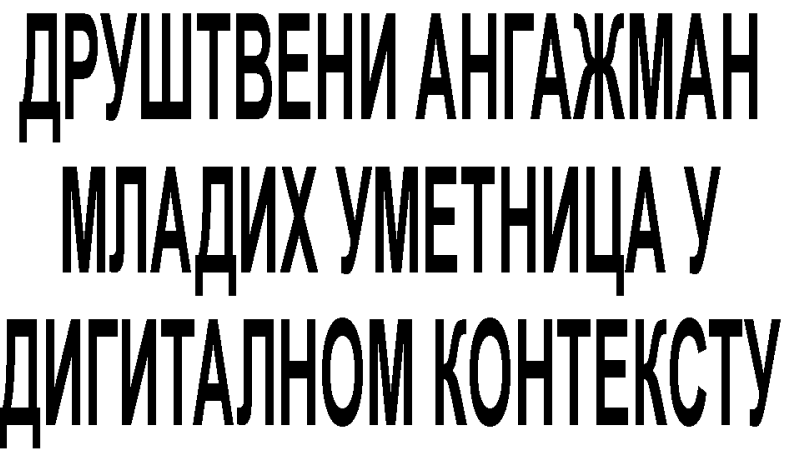

Сажетак: Младе жене заузимају све значајније место у онлајн простору користећи све предности дигиталног доба и стваралачке карактеристике интернета и дигиталних медија. У тексту се испитује да ли и у којој мери младе ауторке из Србије користе своју уметничку продукиију и своје профиле на дигиталним платформама за изражавање друштвенополитичких ставова, и каквих, а посебно какво је њихово разумевање феминизма, родне равноправности и искуство са родном дискриминаиијам. Друитвени контекст прве половине 2020. године током које је рађено истражсивање обележила је пандемија и последично ванредно стане и изолаиија, а поред тога уобичајеном окружену ниховог стваралаштва припада и сексизам у медијима и јавном простору. Истражсивање је обухватило индивидуалне интервјуе са осам ауторки млађе генерачије у различитим уметничким пољима (визуелне уметности, музика, филм, къижевност и извођачке уметности), кроз које је испитивана нихова употреба друитвених мрежа и дигиталних платформи, критичко миишвење и критичка уметничка продукиија, те реакиије на глобалну кризну ситуаиију и дриитвене проблеме.

Кључне речи: критичко мишьење, друитвене мреже, маркетинг уметности, женско стваралаштво, младе жене, феминизам, родна равноправност у кугтури 


\section{$Y_{60 \partial^{L}}$}

Текст се заснива на знању и теоријама из области феминизма и студија рода, нових медија и дигиталних комуникација, те менаџмента и маркетинга у култури.

Одговоре на истраживачка питања ауторка текста је прикупљала кроз директне интервјуе са уметницама на крају (првог) периода ванредног стања, изолације и пандемије у Србији - јун и јул 2020. године, и у одређеној мери етнографском анализом и анализом садржаја одабраних уметница на интернет платформама и друштвеним мрежама (првенствено Фејсбуку и Инстаграму), објављених током периода ванредног стања и изолације.

Ауторка искрено и срдачно захваљује уметницама са којима је разговарала у оквиру овог истраживања, на отворености и посвећености да разговарају и о личним темама. Оне не само да су издвојиле време и енергију, већ су и поделиле неке приватне и интимне дилеме, страхове, несигурности, размишљања, осећања и бриге. Тек све то заједно омогућава суштинско разумевање питања које овај текст поставља и квалитетније осветљава феномене које ћу покушати да представим и анализирам кроз текст.

\section{Медијски, уметнички и друитвени контекст}

Дигиталне платформе за комуникацију, умрежавање и информисање, забаву, пласирање и продају различитих садржаја остварују значајне медијске, друштвене, економске, политичке, али и културне и уметничке сврхе и циљеве. Они се могу сагледати као стубови савремене медијске сцене, са једне стране, али и као све значајнији фактори информисања о уметности, коришћења и доживљавања уметничких садржаја, стваралачке комуникације и размене, промоције, дистрибуције и продаје у сектору уметности и културе. Многа разматрања и концептуализације развијене у домену студија нових медија и дигиталне комуникације су стога релевантне и за поље маркетинга уметности, макар за сегмент који се одвија на дигиталним платформама.

Према истраживању културних потреба и навика грађана Србије, који је Завод за проучаване културног развитка

1 Рад је настао као резултат ангажовања на пројекту „Идентитет и сећање: транскултурални текстови драмских уметности и медија" Факултета драмских уметности бр. 178012 који финансира Министарство просвете и науке РС. Истраживање је делимично спроведено и уз подршку Фонда за науку Републике Србије, програма ПРОМИС у оквиру пројекта ФЛИМ бр. 6066876 . 
спровео 2016. године ${ }^{2}$, интернет за потребе културе [..] користи $62.1 \%$ свих испитаника. Садржаје из културе на интернету свакодневно прати 11.9\%, свих испитаника, неколико пута недељно 14.6\%, и једном недељно 10.7\%. Жене чешhе користе интернет за потребе културе у односу на муику популацију, а са годинама живота опада број корисника интернета у сврху културе. Урбано становништво (42\%) у значајно већем проченту посеһује редовно, односно барем једном недељно, садржаје из културе од становниитва руралних подручја (28.6\%). Чак $80 \%$ високообразованих грађана користи интернет и у сврху културе, док то чини $61 \%$ среднеобразованих и $31.5 \%$ нижеобразованих грађана ${ }^{3}$. Ови подаци младе високообразоване жене у градовима сврставају у најактивније кориснике интернета у сврхе културе.

Савремено медијско тржиште и дигитални простор карактерише пролиферација медијског садржаја: продукција садржаја је значајно појефтинила, снижен је „улазни праг” на медијску сцену, приступ омогућен свакоме (или макар значајно већем делу становништва него што је то било карактеристично за претходне периоде развоја медијског окружења), те се сматра да је дошло не само до веће доступности садржаја већ и демократизације продукције. Медијска продукција на интернету захтева мање почетне инвестиције те је приступ олакшан, а аудиторијум, начелно, глобалнији и потенцијално шири. Слободнија продукција и олакшан приступ (често могу да) иду паралелно са смањењем квалитета садржаја, доминацијом непроверених, непоузданих и ирелевантних извора информација, те губљењем граница приватног и професионалног/јавног. Затрпавање, хиперпродукција, засићеност и преплављеност отежавају проналажење квалитетне и професионалне информације, те способност претраживања и медијска писменост и компетенције постају све релевантнији. Истовремено, сведоци смо фрагментације аудиторијума.

У огромној понуди садржаја, грађани, посебно млади, знатно виие користе информачије до којих долазе путем онлајн медија или друитвених мрежа, при чему у овом прочесу

2 Опачнћ, Б. и Субашић, Б. (2016) Културне потребе и набике грађана Србије, Београд: Завод за проучавање културиог развитка, стр. 179-180.

3 Nikolić, T. (2019a) Android apps as marketing and/or young audience development tools within cultural institutions in Serbia, izlaganje na međunarodnoj naučnoj konferenciji Novi horizonti kulture, umetnosti i medija u digitalnom okriženju, Fakultet dramskih umetnosti, Beograd, 11-14. septembar 2019. 


\section{TATJAHA НИКОЛИЋ}

публика не трага за садржајима, већ садржаји проналазе юи $x^{4}$.

За све претходне феномене и многе друге, карактеристичне за нове медије, дигиталне и мрежне комуникације како их виде бројни аутори ${ }^{5}$, препознају се значајне сличности и сродности са уметничком сценом, системима промоције и дистрибуције уметничког дела, развоја уметничке публике и процеса рецепције макар у дигиталном простору. Ова аналогија једна је од премиса овог текста. Са друге стране, ако сматрамо да макар у одређеној мери, савремене медијске технологије и комуникацијске праксе доприносе развоју е-демократије, теледемократије, сајбер демократије, виртуелне демократије, мобилне демократије ${ }^{6}$, могло би се и очекивати да доприносе и развоју публике за уметничке и културне садржаје који се тим медијским технологијама промовишу и дистрибуирају, као и за јачање културне демократије, унапређењу партиципације како у продукцији, тако и у рецепцији уметничких садржаја, те разноликости уметничке сцене у дигиталном простору.

Дигитализација и нове технологије један су од разлога заито је развој публике постао тако висок приоритет Eвропске комисије и начионалних европских држава. Сматра се да друштвене мреже подстичу људе на активније учешће и интеракиију у свим аспектима живота и да постоји све веhе интересовате за стваралачким доприносом, дискусијом и дијалогом. (Други разлог би свакако био све веће усмеравање институиија културе на тржиите и захтев да у ито веһој мери саме остварују приходе [...]) Према извештају са конферениије „European Audiences: 2020 and beyond"7 одржане 2012. године, развој публике може се остваривати укьучиваьем у креирање програма, стратегије, маркетинга; те дијалогом са публиком о створеном делу - у другом се највећа очекивања полажу управо у друитвене мреже и нове комуникаиијске технологије ${ }^{8}$.

\footnotetext{
4 Nikolić, M. Moć gradana - od participacije u kreiranju sadržaja do medija civilnog sektora, u Mediji civilnog društva kao alternativa medijskom populizmu, senzacionalizmu i lažnim vestima, postkonferencijski zbornik, priredili Gruhonjić, D. i Valić Nedeljković, D. (2019) Novi Sad: Filozofski fakultet, str. 34.

5 Исто; Vukićević, V. (2018) Novi mediji u mrežnoj komunikaciji, Zbronik radova Fakulteta dramskih umetnosti, br. 33, Beograd: Fakultet dramskih umetnosti, str. 207-224.

6 Nikolić, M. нав. дело, стр. 35-36.

7 Европска комисија. European Audiences: 2020 and beyond, закључци са конференције, 16-17. октобар 2012; http://www.culturenet.cz/res/data/016/001795.pdf

8 Nikolić, T. нав. дело.
} 
Интересантно је у овом контексту размотрити и феномен „чувара пролаза" (gatekeeper): да ли постоји „чување пролаза" за гласове младих жена на интернету (нпр. Инстаграму) и како функционише - које су претпоставке тог процеса (gatekeeping-a), ко су актери и чиниоци (stakeholder-и), како процес функционише, кога пропушта, а кога не? Реализовани интервјуи нуде део одговора на ово питање, а интердисциплинарни оквир из којег сагледавамо феномен „чувања пролаза" у овом случају чине женске студије и студије рода, маркетинг у уметности, и теорија и пракса друштвених мрежа.

У сличном смеру ускраћивања или смањења простора за изражавање и деловање, али на другачији начин, на локалне ауторе/ке поред родних и сексуалних стереотипа, предрасуда и очекивања ${ }^{9}$, делује феномен електронског и медијског колонијализма, у којем инострани садржаји, наративи, естетика, аутори и формати произведени у центру/има имају примат и доминирају (мањим) тржиштима (полу)периферије, или пак локалне поруке и наративи бивају измењени, изманипулисани, филтрирани у свом путу ка глобалном аудиторијуму и прилагођени очекивањима, потребама и интересовањима центра ${ }^{10}$.

„Однос Интернета и уметности у Србији указује се као комплексна констелација разноликих дискурса дигиталне културе, културних политика, међународних односа, тржишта, као и могућности самог медија" 11.

Које су друштвено политичке идеје и вредности уметница млађе генерације и како их оне испољавају у оквиру или изван свог уметничког рада на дигиталним платформама и друштвеним мрежама? Како разумеју и ангажују се у феминизму?

Феминистичка уметност уводи нове приступе, субјективности, сензибилитете, периепције и нове форме у свет уметности. [...] Уметност усмерена ка друитвеној и политичкој промени тежи да трансформиие наие разумеваье и доживљај друштвених и политичких проблема, али она

9 Maguire, E. (2018) Hoaxing Instagram: Amalia Ulman Exposes the Tropes of \#Instagirlhood, in: Girls, Autobiography, Media, Palgrave Studies in Life Writing, Palgrave Macmillan, Cham, pp. 175-203.

10 Newsom, V. A. and Lengel, L. (2012) Arab Women, Social Media, and the Arab Spring: Applying the framework of digital reflexivity to analyze gender and online activism, Journal of International Women's Studies, vol. 13, issue 5, pp. 31-45;

11 Mevorah, V. (2015) Internet i umetnost na prostoru Srbije 1996-2013 Odlike umetnickih diskursa na polju Interneta u Srbiji, doktorska disertacija, Beograd: Univerzitet umetnosti, str. 238. 


\section{TATJAHA НИКОЛИЋ}

нема за циль само емпатију и саосеhaьb за nоcmojehe nроблеме. Обећане активистичке уметности је редефинисане разумевања како уметности тако и политике [...] охрабрујуһи нас да свет и пегово функционисаюе гледамо другачије и нудећи нове моделе уметничке продукиије и друштвене организације ${ }^{12}$.

Ако је уметност широко прихваћена као „пројекција будућих светова (утопијских), манифестација жеље за променом, представа директне критике реалности или институција, алегорична форма, симболичка идеја или политичка иронија и сатира”, а дистрибуција уметничких дела „увек политичка - идеолошка", ова ауторка поставља питање, ако се неко уметничко дело бави одређеном друштвеном темом, да ли се одмах сврстава у друштвено ангажовану уметност, или је то просто индивидуални израз уметника на индивидуалну тему у садашњости која му је важна? Постоји ли и колико је важна дистанца између намере уметника и значаја, значења, интерпретације и ефеката неког уметничког рада? Да ли уметност уопште може да се одвоји од политике, иако се у томе дискурзивно покушава већ деценијама, ако је финансирана и подржавана од стране некаквих институција државе, а и ако само егзистира у неком друштвеном (политичком) контексту? Нема уметности која је аполитичка и безидеолошка, сматра Дипвел (Deepwell) у монографији „Феминистичка уметност, активизми и артивизми”"13.

Феминистички уметнички пројекти и феминистички активизам срећу се најчешће у цивилном сектору, често у програмима подршке вишеструко угроженим групама, а заснивају на отворености, сензибилитету и посвећености уметница и стваралачких активисткиња упркос лошим условима рада и изостанку подршке окружењ $\mathrm{a}^{14}$.

Део истраживања посвећен је искуству дискриминације на основу пола и рода и начинима суочавања и разрачунавања са таквим искуствима, посебно у дигиталном окружењу. Према скорашњој студији о условима рада и живота уметница у Ријеци „Како живе умјетнице?” ${ }^{15} 48 \%$ је доживело дискриминацију у друштвеном окружењу, 37\% није, а 15\% не може да процени - „што забрињава додатно јер потврђује

12 Deepwell, K. Introduction, in: Feminist Art, Activisms and Artivisms, Deepwell, K. (ed.) (2020) Amsterdam: Valiz, p. 10.

13 Исто, стр. 10-17.

14 Nikolić, T. (2019б) Umetnički projekti sa migrantkinjama - pitanja kulturnog i rodnog identiteta, Interkulturalnost: casopis za podsticanje i afirmaciju interkulturalnosti, br. 18 , str. 85-96.

15 Banić, S. i Gojić, N. (2018) Kako žive umjetnice?, Rijeka: Prostor Plus. 
колико смо у свим сферама живота континуирано изложене притиску системске дискриминације са једне, те интернализацији кривње са друге стране".

Резултати овог истраживања показали су нам да су уметнице у Рнјеци, а сматра се и у другим сличним срединама, већински биле дискриминисане на основу пола и рода. Оне су трпеле сексистичке коментаре, увреде, потцењивање, сегрегацију, повремено примале ниже зараде у односу на мушке колеге, биле искључиване или изложене критикама због својих приватних или пословних одлука и друго. Кроз интервјуе покушали смо да отворимо и ово питање у домаћем контексту са фокусом на младе ауторке, а ускоро се очекују и резултати шире, београдске верзије овог истраживања ${ }^{16}$.

Ауторке ријечког истраживања су закључиле да је већина испитаница „врло добро упозната са проблемима патријархалне, сексистичке и ксенофобне средине у којој живи, ради или коју због природе професије повремено посећује", и да док неке од њих избегавају сукобе, друге покушавају да разговарају, истрају у свом ставу, неке додатним и прековременим радом покушају да отклоне сумње и критике, деле своја искуства и др ${ }^{17}$. Интервјуи обављени са ауторкама из Србије такође ће да осветле спектар начина на које младе жене покушавају да се, ментално, комуникацијски, пословно или активистички изборе са таквим притисцима из окружења.

Идеја сајберутопизма последње деценије 20. века је одавно превазиђен. Чак и ауторке попут Доне Харавеј, које су предњачиле у тврдњама да ће дигитални свет бити без идентитетских подела и опресије, одавно су препознале да то није никаква „обећана земља" и да технологије само делимично нуде нове могућности, приступ знањима и ресурсима, канале дисеминације уметничког рада и повезивања, али да делимично и рефлектују и продубљују постојеће односе моћи

16 Истраживање „Како живе ум(j)етнице?” у Београду реализују продуценткиње млађе генерације Ксенија Ђуровић и Ана Вуковић, такође некадашње студенткиње на студијском програму Менаџмента и продукције позоришта, радија и културе на Факултету драмских уметности, а уз подршку платформе Заједничко.орг, Шејме Фере, Катарине Поповић, Марије Радоман и програма Мулти Мадеира. Dragosavljević, М. (23. 06. 2020.) Ne radi se o ,jednakosti” - kako žive umetnice i kulturne radnice, Mašina. posl. put pristupljeno 26. 07. 2020; https://www.masina.rs/?p=13899

17 Banić, S. i Gojić, N. нав. дело, стр. 29-30. 


\section{TАТЈАНА НИКОЛИЋ}

из офлајн света ${ }^{18}$, a „извођење” рода на интернету под будним је оком бројних „чувара пролаза" ${ }^{19}$.

\section{Резултати интервјуа и анализе}

За централни узорак у овом истраживању одабрано је осам уметница млађе генерације, тако да припадају различитим уметничким пољима и дисциплинама које се традиционално виде као мушка занимања у уметности и култури: музици (рок и савременој уметничкој), филмској режији, књижевности, извођачким - stand up комедији, визуелним и примењеним уметностима - илустрацији, стрипу и графичком дизајну, а са циљем да се истраживачка питања и хипотезе примене на различита уметничка поља и медије. Одабране ауторке део су београдске, и домаће културне, уметничке и креативне сцене у Србији, неке од њих и са повременим или чешћим ангажманима, наступима и признањима изван граница наше земље, што је било посебно релевантно у анализи коришћења интернета за регионалну и међународну комуникацију, представљање и повезивање, као и реаговање на друштвене теме и проблеме изван граница наше земље и разумевање свог места, улоге, домета и одговорности на ширем друштвеном плану. Саговорнице су одабране на начин да је ауторка текста неке од интервјуисаних уметница познавала лично и имала изграђен однос са њима, који је омогућио да се отворено и лакше разговара и о питањима вредности, ставова, као и личних дилема и преиспитивања, док је са другима ово био први контакт, што осигурава одређену дозу истраживачке дистанце и објективности.

У овом тексту представљени су резултати три батерије питања постављених у оквиру одржаних интервјуа. Прва се односила на друштвено окружење, друштвено политичке проблеме које препознају као приоритетне, и њихову мотивацију и посвећеност да допринесу решавању тих проблема. Друга батерија односила се на идеје, праксе и политике родне равноправности и феминизма: разумевање појма феминизма, процену родних односа на домаћој културној сцени и ширем друштву у Србији, те лично искуство родне дискриминације и сексизма. Трећа група питања испитивала је

18 Newsom, V. A. and Lengel, L. (2012) Arab Women, Social Media, and the Arab Spring: Applying the framework of digital reflexivity to analyze gender and online activism, Journal of International Women's Studies, vol. 13, issue 5, pp. 31-45; Antonijević, Z. (2013) Strategije kiberfeminizma: feminizam na društvenim mrežama u Srbiji, Genero: časopis za feminističku teoriju i studije kulture, br. 17, Beograd: Fakultet političkih nauka, str. 183-208.

19 Maguire, E. (2018) Hoaxing Instagram: Amalia Ulman Exposes the Tropes of \#Instagirlhood, in: Girls, Autobiography, Media, Palgrave Studies in Life Writing. Palgrave Macmillan, Cham, pp. 175-203. 
начин и меру у којој ауторке деле своје политичке и друштвене ставове у дигиталном простору (у оквиру и изван своје уметничке продукщије).

\section{Лични ставови $и$}

\section{друитвено политички приоритети}

Неки од централних друштвено-политичких проблема које младе ауторке препознају и промена које у друштву у Србији морају да се десе су: слабост институција и изостанак поверења у њих, популизам и недостатак истинске политичке визије и правца, корупција, партократија и партијско или рођачко запошљавање - „Превазилажењем личних интереса на свим нивоима би све процветало јер би заслужни кадрови били на позицијама и бринули о заједничком интересу...", социјална неправда - „све дубљи друштвени јаз између грађанства и повлашћених слојева"; медијска сцена и недостатак слободних медија, једноумље и недостатак критичког мишљења, те лоша информисаност у друштву.

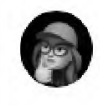

LelaRadan

(@) JelenaRadanovic

\section{RTS - vaše pravo da Džeki Čen \\ Translate Tweet \\ 11:37 PM - Jul 7, 2020 . Twitter for iPhone}

$$
12 \text { Retweets } 89 \text { Likes }
$$

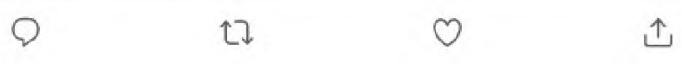

Илустрација 1. „РТС: Ваше право да Џеки Чен”,

љубазношћу ауторке Јелене Радановић

Поред ових, ауторке мапирају као изузетно важне и вербално насиље и изостанак дијалога; доминантне вредности и недостатак толеранције, дискриминацију и угрожена права ЛГБТ и других мањинских заједница, затвореност и недостатак свести; занемаривање културних потреба и културног живота, недовољну подршку култури; уништавање и загађеност животне средине; небригу о менталном здрављу; централизацију економског и друштвеног живота у Београду; те запуштеност јавног образовног, и здравственог система.

Приликом разговора на тему друштвено политичких проблема и приоритетних промена, младе ауторке се често устручавају да изразе отворено своје мишљење, сумњајући у своју компетенцију да о макрополитичким, економским, социјалним и другим питањима говоре или им допринесу, или о свом праву да коментаришу, понекад с обзиром да 


\section{TАТЈАНА НИКОЛИЋ}

нису сигурне да ли се у „довољној мери” саме ангажују на решавању препознатих проблема. Овим темама приступају озбиљно, одговорно и самосвесно.

1.1. Трудим се да не размишьам о стварима које ја не могу да променим, или у којима ја лично не желим да се ангажујем. [...] Поито је то толико велико и преплављуjуће, а ја не радим у том домену, ондами је ефикасније да радим оно ито ја могу.

1.2. Трудим се да не размииљам много о политици, јер не мислим да сам компетентна у том смислу.

Осећања која доминирају када говоре о друштвено политичкој ситуацији у Србији су незадовољство, разочарање, безнадежност, беспомоћност, песимизам, безизлазност, резигнираност, љутња, очај.

Оне такође претежно избегавају да дефинишу своју циљну групу и друштвену групу / културни модел којем се обраћају својим стваралаштвом - визуелним, музичким, филмским, књижевним и др. Иако је део саговорница био свестан, упућен и информисан ко чини њену групу пратилаца, корисника или посетилаца њених садржаја и програма, већина је објашњавала да се приликом самог стваралаштва не обраћа ниједној групи или профилу интенционално, већ да углавном производи садржаје из личне потребе и инспирације, а потом ти садржаји пронађу своје даље адресе.

2.1. Не разиииьам о публици, размииљам вище о себи...

2.2. Искрено, не знам... Некад не знам да ли уопите пиием за неку циљну групу или онако инстинктивно.

2.3. Ја када стварам свој садржај и пласирам га немам циљну групу коју таргетирам. Али саи схватила морам вище да се позабавим тиме ко дели моје садржаје, па сам инсталирала аналитике и могу тачно да кажем ко ме прати и дели и до кога су моје поруке стигле.

2.4. Овде нема стратегије. То би ми било важно да је активистички пројекат, или да је регионална продаја. $A$ поито су ово арт пројекти могу да радим шта хоһу.. Ко he се са тим повезати и пронаћи ја не могу да навигирам.

2.5. Jа уопите на почетку овог концепта пре годину дана нисам се обраћала никоме, већ самом себи, требало ми је да ми неке ствари дођу до главе. И даље немам ииљну групу којој се обраћам, јои увекискьучиво радим то само због себе, то је себично али тако је. Кад будем кренула да се обраћам некој ииљној групи, боље да престанем да радим. Ово није комериијалне природе. 


\section{TATJАНА НИКОЛИЋ}

2.6. Jа се вечито трудим и желим да прићем широј групи, и тинејиере у средњој школи да привучем, да се заинтеpecyjy...

Разговарала сам са младим уметницама и о томе да ли оне желе, да ли активно покушавају да допринесу и укључе се у решавање неких од наведених друштвених и политичких проблема, и какав је њихов однос према активизму, било кроз свој уметнички рад или изван њега. Један део саговорница говорио је да жели да допринесе и укључи се, али да их спречава недостатак времена, финансија, подршке, да не верују да могу да направе икакву промену, да немају капацитета и потенцијала, као и да се не би осећале безбедно уколико би више и директније износиле друштвене и политике критике у свом јавном наступу и раду.

3.1. Депримира ме све ито се дешава, па ми не остане енергије да осмислим пројекат. У наиој клими кад бих кренула да радим неито велико, запажено и критички, нисам сигурна да ли бих имала храбрости тиме да се бавим - има их свуда, гледају све. Такође, овде је теико направити нешто велико и значајно - пројекти који не иду под руку естаблиштменту у региону тешко и да долазе до адекватне финансијске подрике.

3.2. Знам да би, да ја то кренем да радим, моја мама имала проблема на послу.

И док често не виде себе као активисткиње, и избегавају да свом уметничком раду доделе и неки активистички, друштвени или политички циљ, део ауторки поделио је како их искрено радује, мотивише, испуњава када њихово стваралаштво емотивно или ментално дотакне другу особу, када постоји разумевање, комуникација, размена и када утичу на расположење или осећања своје публике и пратилаца. Ово се поставља као важна димензија њиховог рада када је реч о утицају на друге особе и на друштво, поред наравно, основне потребе за унутрашњом комуникацијом и реакцијом на унутрашње потребе, наративе, идеје и осећања.

4.1. Мени је страшно драго кад нешто што ја наиртам је људима симпатично, насмеје их или испровочира неку реакиију.

4.2. Кад неко и подели утисак и мишьете и неку емочију коју је доживела/о захваљујући неком мом раду, учини ми велику част и задововство.

4.3. Ја на суени кажем неки стереотип, ми се насмејемо, али нешто и изазовемо на тих пар минута, поставимо numarbe. 


\section{TATJAHA НИКОЛИЋ}

Оне тако комуникацијске димензије свог стваралаштва виде као микро-утицај на свакодневицу, расположење или мишљење својих пратилаца, углавном без претензија, амбиција или очекивања да утичу на промену свести или ставова по друштвеним или политичким питањима.

5.1. Кроз мале уметничке пројекте људима даи нешто ито и не очекујеи и не планираи. Видии анестезиологе на ГАКу који носе „Само нежно према себи”, смирују труднице твојим беиом. [...] Потпуно је сулудо, не можеш ни да претпоставиш шта һе ту да се деси и развије. Зато ми се чини непотребан труд да кренем од кровних ствари и великих тема, кад кроз конкретан пример видим да и мали дизајнерски активизам може да прокрчи пут до нивоа до којих ја не могу да дођем институционалним каналима.

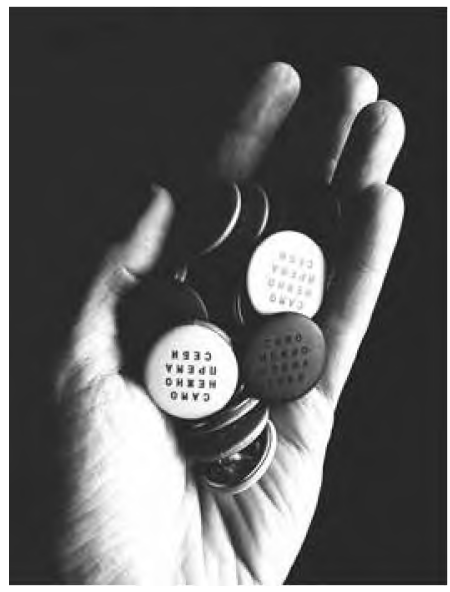

Илустрација 2. „Само нежно према себи”, љубазношћу ауторке Јане Оршолић

Постоје наравно и изузеци које је важно на овом месту препознати. Филмска ауторка Ивана Тодоровић континуирано поставља тешка и комплексна питања и потресне теме у средиште свог документарног стваралаштва, предано бирајући да се суочава са табу темама и подиже свест у друштву о друштвено осетљивим групама и насилничким матрицама понашања са којих нам је лакше да скренемо поглед; комичарка Јелена Радановић повремено у своје наступе интенционално позиционира и наративе о насиљу над девојчицама и женама, и иако их представља у форми вица и шале својствене послу који ради и креативном изразу стендап комедије, то истовремено представља и свесну интервенцију у јавном дискурсу коју је ауторка могла да изабере и да не изводи; и др. 
Према Дипвел, феминистичка уметност бави се крупним политичким питањима и политикама, али и замагљује / дискутује линију разграничења јавног и приватног, инсистира на личном као политичком и тиме утврђује значај микрополитика свакодневног живота. Феминизам инсистира да је „приватна сфера" - дом, породица, друитвено уређене односа, одржсаваье и репродукиија самог жсивота - неодвојива од „јавне”, те у политику уводи читаве области друитвених, сексуалних, психолочиих и емотивних тема. Такође, феминизам пледира за преиспитивање граница између продукције и репродукције - односно боље разумевање друштвене репродукције живота - љубави, бриге у породици, организацију рада, институција здравственог и образовног система - области које су третиране као мање вредне, а што су често мотиви или теме, формати или контексти феминистичког (и женског уопште) уметничког рада ${ }^{20}$, и које управо срећемо у значајном делу опуса ауторки које су предмет овог пилот истраживања.

\section{Феминизам, родна (не)равноправност и дискриминачија}

Ауторке процењују да је Србија далеко од родне равноправности, да мушкарци и жене нису једнако третирани у друштву, и да је дискриминација свеприсутна, илуструјући то са једне стране личним примерима, а са друге стране медијским дискурсом, неједнаким присуством на позицијама моћи у друштву, примерима из пословног окружења и другим. Међу одговорима препознаје се спектар начина суочавања са дискриминацијом и сексизмом, али и преиспитивање сопствене позиције и реакције. Неке од саговорница истичу да и у другим, развијеним земљама постоје слични проблеми, као и да оне лично нису у својој породици и уском пословном окружењу имале негативна искуства. Током дужег разговора, пак, и ове ауторке присете се, те наведу различита искуства која се могу сврстати под неравноправни третман, и посведоче о оптерећењима или очекивањима која постоје према њима с обзиром на пол (род).

6.1. Сви људи који су исправни немају те идиотске коментаре на мушко - женске теме, али они који нису исправни и иначе у приватном жсивоту и на послу причају будалаитине. Ти људи се код мене одмах дискредитују и виме се не бавим њима.

6.2. Ја сам имала mу срећу да нисам осетила ту дискриминацију на својој кожи, нити у наиој земьи. Имамо

20 Deepwell, К. нав. дело, стр. 17. 


\section{TATJAHA НИКОЛИЋ}

професоре на академији женског рода, композиторке итд., није деловало као проблем за образовање и напредовање, док сам скоро схватила да у Америци и у Немачкој се то веома осећало и композиторке и уметнице су имале проблеме.

6.3. Трпим разне видове диксриминаиие чим изађем из зграде.

6.4. Друитво је у ретрадиционализацији, у много чему стагтирамо, а у понечему смо и назадовали.

Неке од ауторки као да осећају да не могу да се буне и буду критички оријентисане јер њихова искуства нису тако негативна, а положај угрожен као неком другом. Стога оне овакве ситуације нормализују, очекују од себе да се изборе или изолују, не потресају, буду чврсте и на тај начин учине проблем мањим или непостојећим. Укратко, талентоване, способне, одговорне и посвећене младе жене преузимају и ову одговорност и посао на себе.

Уз поједине изузетке, слажу се у оцени да културна сцена није равноправна и да нису подједнако заступљене уметнице и уметници, да нема довољно жена које воде културне организације и да недостаје подршке. Са друге стране, процењују да постоје позитивни помаци и да се дешавају промене и побољшања.

7.1. Апсолутно је родно равноправна, сигурно није ником спречен рад или напредовање. Дешавају се те неке неједнакости, које испадну спонтано, неке ствари су биолоике..

7.2. Чула сам да у култури има виие жена, али су то у суитини најматье плаћене делатности, чини ми се да је то тачно. На већини директорских позичија су муикарчзи и даље.

Општи проблеми политичке природе, корупција и непотизам, а потом и мали капацитети и финансијске могућности сектора културе и неразвијене културне потребе међу становништвом Србије, према речима неких од саговорница, вишеструко су значајнији проблеми и препреке за напредовање и остваривање креативног и индивидуалног потенцијала у Србији и региону.

8.1. Тренутно је у Србији у културној политици најважније да ли си политички подобан, а тек онда се врии даве раслојаваюе. Мора прво да се повећа буиет за културу, потом да се јасније одреде ииьеви и визија, а тек онда итоо се инктузивности тиче. Можда звучи смешно, 


\section{TATJАНА НИКОЛИЋ}

али мислим да су квоте неопходне, док нам не уђе у менmaлuтет.

8.2. Муикарии и жсене имају једнаке прилике, ми уопите немамо тај проблем, осим политичког. Али верујем да сигурно има неких предубеђења која могу да спрече дечу. мада данас виие нема толико ни везе са половима, деуа су уопите спречена да се окрену уметности, музици, креативности.

Иако је свака саговорница поделила неко, често значајно и систематско искуство дискриминације, сексизма и патријархата које је доживела у различитим окружењима, велики број њих сумња у своју компетентност да о тој теми говори, даје оцене или коментарише, уступајући простор за такву конверзацију некима који су „стручнији”. Делимично, ово је значајно и са аспекта препознавања сопствених привилегија, као и одговорности за изречену реч и јавно деловање, што је свакако валидно и вредно поштовања, али се у великој мери примећује и утишавање сопственог гласа, непрепознавање сопственог мишљења као довољно релевантног и уступање простора неком другом. Поставља се питање да ли и какав простор за интервенцију у овом домену постоји на уметничким високошколским установама и да ли је могуће да се оне укључе у изградњу ове врсте компетенција и вештина уметница/ка, имајући у виду институционална ограничења патријархалног контекста у којем, упркос свим напорима појединаца/ки, функционишу.

9.1. Највиие волим да причам о свом искуству јер нисам ни антрополог ни сочиолог па није у реду да дајем неке опите очене. Свесна сам да моје мииљене ипак има везе и са мојим околностима, Београд итд., ствари су негде другде можда другачије.

9.2. Мораи прво да се образујеи, ако одеш у погреином смеру можеши да направии итету. Боље да не кажем, него да љууи чују нешто погрешно. Не бих волела ни да неко мисли да се ја нешто правим паметна..

Саговорнице су често делиле и своја очекивања да мизогинија, патријархат и сексизам треба да буду мање доминантни међу женама, те разочарање што то често није тако, и неопходност удруживања, женске солидарности и подршке.

10.1. Морам да признам да ја ту имам проблем са женама у целој тој причи, и са мамама, са женама којима је такво понашағье океј.

10.2. Морају и жене да престану да се смеју у великим колективима на глупе сексистичке форе, а и саме да их про- 


\section{TATJАНА НИКОЛИЋ}

изводе. Када заузиеш прави став, то јесте болно-увек је бити другачији болно, али на дуже стазе је продуктивно, почну да те сматрају колико - толико равноправном.

10.3. Много болно је и што су жене жени јако често вук. Трпела сам у више наврата дискриминацију због својих избора и начина живота од стране жена.

10.4. Док ми не направимо наи чопор, појединачно не можемо ниита.

Један од циљева истраживања односио се и на мапирање различитих приступа феминизму и разумевања овог појма и покрета. Ауторке су све о феминизму говориле у позитивном тону, сматрајући феминистичке вредности делом савремене цивилизације, људским и грађанским правима, човечности и равноправности. Истовремено, већина је потврдила и да се о феминизму углавном говори о негативном контексту, као о агресивном, милитантном, радикалном покрету „против”.

11.1. Просто то је борба за једнака права свих људи без обзира на род, пол и остало. Ја то видим као иирок покрет за друитвену правду; 11.2. Борба за људска права, као и антирасизам, неохходан покрет.

11.3. Ја сам чула да су то жене незадовољне собом, али међутим то није тачно, то су жене које желе нешто да промене и држе до себе, ја то тако видим, и које имају довољно самопоитована да се са овом наиом свакодневницом изборе, да се боре за своја права.

11.4. Феминизам је за мене поштовање жене, заитита жене и уважавање жене као личности. Мислим да је феминизам неохходан и да је то једини начин да се положај жена у друитву промени.

\section{5. Начин мииьеьь и пут сазнања;}

11.6. Борба за освешћивање жена.

11.7 Појам људске једнакости - да је свако биће једнако битно ваюсно и негово време и слободно и радно и снови... Појам човечности. Надам се дану кад ће то бити једина могућа опиија и природно понаиање.

У односу на очекивања пре почетка истраживања, постфеминизам $^{21}$ се у спроведеним интервјуима препознаје у значајно мањој мери. Ниједна од саговорница не сматра да је

21 Veseljević Jerković, S. (2012) „Ti si superžena”: nova ženstvenost u popularnoj kulturi, Genero: časopis za feminističku teoriju i studije kulture, br. 16, Beograd: Fakultet političkih nauka, str. 117-140. 
равноправност постигнута, феминизам ирелевантан и борба непотребна, иако је ово „патријархална дискурзивна стратегија" који се у великој мери среће међу младим, активним и самосталним женама данас ${ }^{22}$. „Постфеминистичку визију супержене", по којој жене данас могу имати све ако су довољно способне - а ако немају, то је зато што оне нису компетентне, а не јер постоје структурни фактори који то онемогућавају, моје саговорнице ретко подржавају.

Поред свега наведеног, део ауторки често се и свесно суочава са стереотипима у вези са професијама, способностима и интересовањима мушкараца и жена, претпостављањем њихове сексуалне орјентације, коментара на рачун физичког изгледа, година или сексуалног или породичног понашања и избора, а то све још у већој мери препознају у јавном и медијском простору. Због стереотипа и очекивања средине (личне, професионалне и шире јавности) неке од саговорница имају тешкоће у психолошком усклађивању професионалног, родног и сексуалног идентитета и то представља додатно оптерећење, а о чему постоје и релевантни уметнички пројекти који то пропитују ${ }^{23}$. Неке од њих преиспитују своју женственост, покушавају да је заштите, конструишу што независније од спољашњих друштвених очекивања, и у томе су значајни узори и модели, потенцијалне или реалне менторке у професионалном развоју. Ауторке се суочавају са микроагресијама, неадекватним тоном, избором речи или говором тела у професионалној комуникацији, нежељеним коментарима, проценама и нетраженим саветима од људи који им нису блиски као и претпоставкама да су њихова постигнућа или интересовања заслуге мушких партнера. Још једном се показује да женско тело, избори и живот као да се сматрају јавним и као да су сви позвани да их коментаришу и процењују.

НІала на рачун жена може се много лакие и са више успеха изрицати од шале на рачун муикариа. Ове шале су често вулгарније и много виие се односе на тело и телесност но иале које су усмерене ка муикости (ту се јављају и иале на рачун амбииије, сигурности и сл. - тзв. муиких вредности $)^{24}$.

22 Исто, стр. 127.

23 Maguire, E. (2018) Hoaxing Instagram: Amalia Ulman Exposes the Tropes of \#Instagirlhood, in: Girls, Autobiography, Media, Palgrave Studies in Life Writing, Palgrave Macmillan, Cham, pp. 175-203.

24 Dragićević Šešić, M. Mizoginija u obrascima masovne kulture, u: Mapiranje mizoginije u Srbiji: diskursi i prakse (prvi tom), priredila Blagojević, M. (2000) Beograd: Asocijacija za žensku inicijativu, str. 372-373. 
Неке од ауторки суочавају се са инфантилизацијом или објектификацијом, али онда повремено покушавају да, у том ограниченом спектру могућности, те стереотипе и ограничења преокрену у своју корист. Уз оптерећење својим физичким изгледом и временом и енергијом уложеним у улепшавање (било да преиспитују да ли довољно, или превише времена посвећују овим активностима), код неких од ауторки препознаје се и оптерећење да оне представљају на неки начин све друге жене, да говоре у име свих, као и да друге жене у одређеној мери представљају њих, и постављају од њих очекивања која оне после морају да испуњавају, или оповргавају. Све то појачава идеју о женској компетицији, сујети, и да „може бити само једна” што додатно отежава и лични и професионални развој, комуникацију и изражавање младих ауторки у домаћем и регионалном контексту.

\section{Употреба дигиталних платформи и}

\section{критичко мииьење}

Уз анализу српског сајбер простора и сајбер културе - њихових граница, актера, процеса настанка и развоја, у свом докторском истраживању 2015. године Вера Меворах указује и на недовољну проблематизацију језика нових медија на простору Србије као и недовољно промишљање и деловање културних (и научних) институција у домену дигиталног развоја друштва у Србији ${ }^{25}$.

Младе уметнице са којима сам разговарала су у значајној мери присутне у том сајбер простору и на дигиталним платформама, али углавном не раздвајају своје приватне канале комуникације на друштвеним мрежама, од канала намењених професионалној афирмацији и промоцији свог уметничког рада, док је продаја најмање релевантан циљ за већину. Инстаграм је по њиховом мишљењу, а и по пракси, адекватнији за професионалну употребу од Фејсбука, док је на овој мрежи страница очекивано сматрана професионалнијом од профила. Неколико модела присуства и комуникације на дигиталним платформама које примењују ауторке млађе генерације су:

- Личне и професионалне дигиталне комуникације се преплићу и мешају. Ауторке не маре за то много, јер свакако не дају велики значај том аспекту свог рада и немају амб́иције да се дигиталном промоцијом стваралаштва баве професионално.

25 Mevorah, V. (2015) Internet i umetnost na prostoru Srbije 1996-2013Odlike umetnickih diskursa na polju Interneta u Srbiji, doktorska disertacija, Beograd: Univerzitet umetnosti. 
- Ауторке имају више дигиталних канала комуникације и на различитим каналима у мањој или већој мери деле приватне, односно професионалне садржаје. Остављају пратиоцима и колегама на избор и вољу на којим каналима их прате.

- Коришћење опщије „Блиски пријатељи” или сторија уместо поста, на мрежама које су претежно професионалне, у случајевима када постоји жеља за дељењем неког приватнијег садржаја.

- Одрицање од приватног простора и фокусирање на професионалну комуникацију. Ауторке одлучују да углавном не деле своје ставове на интернету, или/и не деле садржај у вези са породицом. У овом случају долази до својеврсне аутоцензуре из професионалног разлога, али и из сумње у адекватност и усклађеност приватног идентитета и приватних интересовања, ставова и активности са професионалним идентитетом.

12.1. Осећам се да је мој живот јаван због спечифичности посла. Да је то лични простор другачије бих водила.

12.2. Раздвајам тако ито сам од тренутка кад сам одлучила да промовишем своју музику на интернету и друитвеним мрежсама ограничила свој лични простор и не користим на тај начин друитвене мреже.

12.3. Не раздвајам, трудим се да друитвене мреже користим као професионалне канале.

Код значајног дела саговорница постоји својеврсно дистанцирање од планске, структурисане и професионалне дигиталне комуникације, сумња у своје компетенције, недостатак интересовања, представа да је то нечији туђи домен за који оне нису способне.

13.1. Све у животу радим по осећају и то сам укратко ја. Како ми дође данас, сутра већ друга прича. Немам живаиа да то планирам. Мислим да се јако види кад неко ради испланирано, и мени је то исфолирано и безвезе, и то виие не бих била ја.

13.2. Све користим као неки дневник, не обраћам толико пажтьу како је то упаковано. Заправо могу да кажем да сам поприлично лоши „, пкер” онога ито радим. 


\section{TATJAHA НИКОЛИЋ}

Супротно од већине медија у савременом медијском простору у Србији, а и глобално ${ }^{26}$, младе ауторке уметничког и донекле медијског садржаја у дигиталном простору, занемарљиво се баве својом публиком, њеним интересовањима, очекивањима и потребама, и тек у ретким ситуацијама обликују тај садржај уопште имајући је на уму. То, наравно, има своје негативне стране и последице са аспекта дисеминације и дистрибуције уметничког садржаја и дигиталних пракси развоја публике. Нарцизам, који се традиционално приписује контексту друштвених мрежа и генерацијама које су на њима најактивније ${ }^{27}$, није препознат у разговорима нити у презентацијама ауторки на овим дигиталним платформама.

Ауторке које интересује да учествују у јавном дискурсу на друштвене и политичке теме, и да се изјашњавају по важним питањима, често сматрају да су њихови ставови јасни на основу радова и да нема потребе да их експлицитно изражавају, а такође не желе да досађују својим пратиоцима и да их тиме одбијају. Неке од њих пак, сматрају учешће у јавним дискусијама, активистичким процесима и ширењу релевантних информација, својом, не само грађанском, него и професионалном улогом.

14.1. Мислим да изражсавам оно што се у најиирем контексту може назвати грађанским правима. Нисам симпатизер ниједне странке никад била, али увек говорим о грађанским слободама и правима.

14.2. Свој Фејсбук профил користим за промоцију својих филмова и радионица, али не суздржавам се да се изјасним везано за друштвено политичке ставове када за то имам потребу.

14.3. Главни проблем је иензура... Десило се да је један мој твит, који нема везе са политиком (sic!) „РТC: Ваие право да Џеки Чен”, заврии на мајииама, и на то сам баш поносна. Питали су ме да ли хоћу да их тужим за ауторска права - напротив, мени је драго ако ми онда лакие запамтимо да су они пуитали цекија Чена док су иили протести испред тьхх. Јуудима је то смешно, али ја се питам да ли су свесни колики је то проблем и ита је заправо порука иза тога.

26 Nikolić, M. (2010) Budućnost srpskog medijskog prostora - kreativno vs. komercijalno, Kultura: časopis za teoriju i sociologiju kulture $i$ kulturmu politiku, br. 128, Beograd: Zavod za proučavanje kulturnog razvitka, str. 153-154.

27 Maguire, E. (2018) Hoaxing Instagram: Amalia Ulman Exposes the Tropes of \#Instagirlhood, in: Girls, Autobiography, Media, Palgrave Studies in Life Writing. Palgrave Macmillan, Cham, pp. 175-203. 


\section{TАТЈАНА НИКОЛИЋ}

14.4. Читав један мој концепт је настао 2014. кад су биле поплаве, тад сам се можда највише и ангажсовала. Радила сам потопљене багере у Колубари. То је била катастрофа, ми нисмо имали воде 15 дана у Лазаревиу, нестајала је струја, магистрала је била поплављена, били смо одсечени од света; а људи дижу иене у продавницама.. Нема уља, нема ничега, и ја сам тад, тј. после кад је било могућности, урадила огромну ситоитампу, сад имам и литографију ${ }^{28}$.

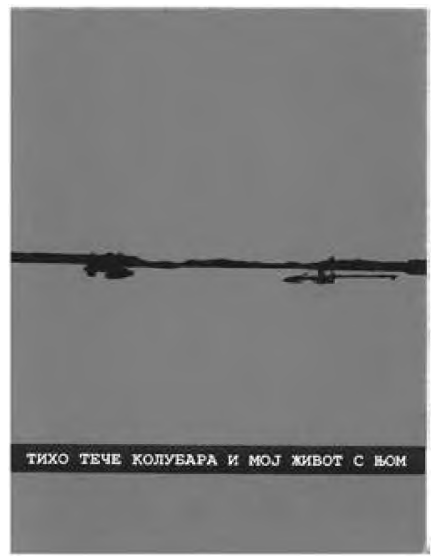

Илустрација бр. 3 „Тихо тече Колубара и мој живот с њом”, љубазношћу ауторке Јелене Милићевић

$$
\text { Закьучак }
$$

Међу уметницама млађе генерације у Србији постоји значајан непрепознат потенцијал и таленат како за ауторску продукцију у различитим доменима и професионалну афирмацију на домаћој, регионалној и међународној сцени, тако и за укључивање у активистичке, друштвене и политичке покрете и јавни дискурс о различитим локалним и глобалним проблемима. Културна сцена у Србији поседује овај значајан ресурс који би значајнијом подршком институција, организација и медија допринео разноликости, квалитету и прогресивности домаћег креативног сектора на међународном плану.

Ипак, ауторке саме не изражавају у значајној мери амбицију и не односе се плански према својој професионалној афирмацији. Претежно не виде одређену друштвену групу као своју циљну групу, и иако су понеке свесне и информисане

28 Овај рад је Центар за културу Лазаревац, одакле је ауторка, откупио уз подршку Министарства културе у 2019. години. „Тихо тече Колубара и мој живот с њом" Јелене Милићевић (1992) један је од шест радова одабраних на конкурсу за који се пријавило чак стотину и четири аутора. Међу само неколико изабраних су, например, још Урош Ђурић и Селман Тртовац. 


\section{TATJAHA НИКОЛИЋ}

о томе ко им је доминантна публика, оне нису ту групу одабрале свесно и определиле се да се њој обраћају. Оне стварају за себе и због себе, и препуштају да садржај „дође до оног кога се тиче". У анализираним случајевима, то што је уметнички рад објављиван и дистрибуиран на друштвеним мрежама, омогућава глобалност и приступ међународном тржишту, сцени и публици само до одређене мере и у партикуларним ситуацијама. Превазилажење географских ограничења у промоцији и дистрибуцији је тек могућност, са много препрека у реализацији.

Младе ауторке у Србији, као и колегинице у Ријеци, уз начелно позитиван став према феминизму, препознају неравноправност мушкараца и жена у ширем друштву, и искусиле су велики број пута дискриминацију и ниподаштавање. У послу и у оквиру културне сцене сматрају да су боље третиране у односу на просечан положај жена у друштву, с тим што се препознаје значајно оптерећење условљено очекивањима, предрасудама и стереотипима, сексизмом и мизогинијом у професионалним круговима, чак и када ауторке нису на тај начин о томе говориле. Поставља се питање користи и штете за саму уметницу уколико би (пре)познавала и критиковала неправедан третман у професионалном контексту, те мотивације да покушавају саме да изналазе начине да се са њиме суоче пре него да посежу за другим средствима и приступима. Ауторке су говориле о искуствима осуђивања у случају било каквих избора, попут оног да се оснује, или пак не оснује породица. Чини им се да постоје позитивни помаци у равноправности унутар културне сцене и уметничког и креативног сектора, што нас радује и надамо се да ће се културна политика и менаџмент у том смеру у Србији и развијати у наредном периоду.

У тексту о мизогинији у масовној култури са почетка миленијума, Драгићевић Шешић утврђује у том контексту да интернет још увек није створио нове културне обрасие и вредности ${ }^{29}$, а бројна истраживања, међу којима и ово чије смо резултате представили овим текстом показала су да, ни две деценије касније, нисмо много одмакли, те да су сексизам, патријархат и мизогинија свеприсутни како у онлајн, тако и офлајн просторима. Обрасци су исти, структуре митова су исте, стереотити и предрасуде, само се садржсаји митова и легенда разликују.

29 Dragićević Šešić, M. Mizoginija u obrascima masovne kulture, u: Mapiranje mizoginije u Srbiji: diskursi i prakse (prvi tom), priredila Blagojević, M. (2000) Beograd: Asocijacija za žensku inicijativu, str. 404

30 Исто. 
У погледу коришћења дигиталних платформи, ауторке, упркос значајном стваралачком и уметничком, те и пословном потенцијалу, претежно не раздвајају у значајној мери приватне од професионалних канала комуникације на интернету. Поставља се питање да ли то сугерише и замагљену границу између приватних и професионалних идентитета, што је изузетно често случај код уметничких професија, а посебно специфично у контексту активизма, и феминизма. Делимично, разлог лежи и у својеврсном одрицању уметница од способности и компетенција да се професионални канали комуникације негују, нелагоди приликом професионалног, промотивног и продајног комуницирања на мрежама, а потенцијално и недостатку смелости да се томе озбиљније посвете и уложе значајније ресурсе (време, енергију, новац). Као и у неким другим сферама у култури, уметничком стваралаштву и креативним индустријама, упркос значајном таленту, квалитету рада, аутентичности, оригиналности и посвећености, препознаје се недостатак самопоуздања, као и несигурност, превелик осећај одговорности и нестабилност положаја и каријере. Ови фактори младе ауторке наводе или да се уздржавају од преузимања значајнијих професионалних корака и гласнијег и друштвено ангажованијег иступа ${ }^{31}$, или да се самосагоревају и исцрпљују ${ }^{32}$. Ауторке углавном немају стратешки и плански однос према својим (потенцијално) професионалним дигиталним платформама, и на њима се делимично цензуришу о личним и о политичким ставовима.

На основу свега наведеног, могуће је скицирати одређене препоруке за деловање релевантних актера. Образовне институције у домену уметности, а и друге, морале би да препознају своју одговорност у развијању критичког мишљења, изградње друштвено политичких ставова и одговорности, као и самопоуздања, емотивне и социјалне интелигенције својих студенткиња, и студената како би оне/и били у могућности да у потпуности разумеју, максимално вреднују и искористе своје таленте и потенцијале. Са друге стране, образовни програми могли би у већој мери да укључују јачање капацитета у области промоције уметности, маркетинга, дигиталне комуникације и умрежавања, као и продаје. Овакви програми подршке и едукације добродошли су и

31 Nikolić, T. (2016) Rodni odnosi na alternativnoj muzičkoj sceni Srbije $i$ regiona, Novi Sad: Zavod za ravnopravnost polova AP Vojvodine.

32 Barada, V. and Primorac, J. Non paid, under paid and self-exploiting labour as a choice and a necessity: example of women in creative industries, in: Young Women in Post Yugoslav Societies: Research, Practice and Policy, ed. Adamović, M. et al. (2014), Zagreb: Institut za društvena istraživanja, str. 143-164. 
из цивилног сектора или специјализованих организација сензибилисаних за феминистичке праксе у култури, у циљу развоја културног менаџмента, маркетинга и културне политике који би тежили родној равноправности и пружали значајније прилике и простор женском и феминистичком стваралаштву у којем се према спроведеном истраживању налази значајан квалитет и потенцијал за допринос домаћој онлајн, и офлајн културној сцени.

Неке од саговорница нису информисане о праксама и политикама родне неравноправности у домаћем, и иностраном сектору културе, док неке препознају проблеме политичке и економске природе као приоритетне, у оквиру конструкције свог идентитета радника/це у култури, али и ангажованог грађанина/ке, који доминирају над родним идентитетом. Иако се у потпуности слажемо у томе колико партократиja, корупција и ограничене финансијске могућности сектора културе неповољно утичу на развој културног живота и услове рада актера у пољу, ово је и сигнал организацијама и институцијама које се баве унапређењем родне равноправности у култури да се активније упусте у истраживања, као и промоцију резултата које добију, те јавне заговарачке кампање укључујући шири фронт ауторки. Поред тога, менторски односи са другим, искуснијим ауторкама, као и умрежавање и удруживање појављују се као позитивна пракса у подршци, личном и професионалном развоју младих уметница.

Како је претходни период у Србији био изузетно буран због ванредне здравствене ситуације, али онда и друштвене, политичке, економске, саобраћајне, психолошке и др., неке од ауторки биле су активније на Интернету и друштвеним мрежама, између осталог и у испољавању своје критике упућене различитим доносиоцима одлука и лидерима.

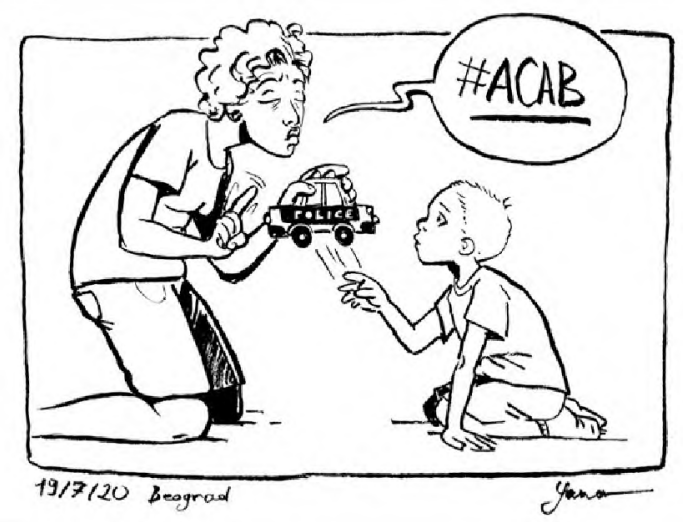

Илустрација бр. 4, „АСАВ”, љубазношћу ауторке Јане Адамовић 


\section{TATJАНА НИКОЛИЋ}

\section{ИЗВОРИ И ЛИТЕРАТУРА:}

Antonijević, Z. (2013) Strategije kiberfeminizma: feminizam na društvenim mrežama u Srbiji, Genero: časopis za feministicku teoriju i studije kulture, br. 17, Beograd: Fakultet političkih nauka, str. 183-208.

Banić, S. i Gojić, N. (2018) Kako žive umjetnice? Rijeka: Prostor Plus.

Barada, V. and Primorac J. Non paid, under paid and self-exploiting labour as a choice and a necessity: example of women in creative industries, in: Young Women in Post Yugoslav Societies: Research, Practice and Policy, ed. Adamović, M. et al. (2014), Zagreb:

Institut za društvena istraživanja, str. 143-164.

Deepwell, K. Introduction, in: Feminist Art, Activisms and Artivisms, ed. Deepwell, K. (2020), Amsterdam: Valiz, pp. 9-20.

Dragićević Šešić, M. Mizoginija u obrascima masovne kulture, u: $M a-$ piranje mizoginije $u$ Srbiji: diskursi i prakse (prvi tom), priredila Blagojević, M. (2000) Beograd: Asocijacija za žensku inicijativu, str. 371-404.

Dragosavljević, M. (23.06. 2020.) Ne radi se o,jednakosti ${ }^{\text {cc }}$ - kako žive umetnice i kulturne radnice, Mašina. posl. put pristupljeno 26. 07. 2020; https://www.masina.rs/?p=13899

Европска комисија. European Audiences: 2020 and beyond, закьучуи са конференције 16-17. октобар 2012. http://www.culturenet.cz/ res/data/016/001795.pdf

Maguire, E. (2018) Hoaxing Instagram: Amalia Ulman Exposes the Tropes of \#Instagirlhood, in: Girls, Autobiography, Media, Palgrave Studies in Life Writing, Palgrave Macmillan, Cham, pp. 175-203; https://doi.org/10.1007/978-3-319-74237-3_8

Mevorah, V. (2015) Internet i umetnost na prostoru Srbije 1996-2013 - Odlike umetničkih diskursa na polju Interneta u Srbiji, doktorska disertacija, Beograd: Univerzitet umetnosti.

Newsom, V. A. and Lengel, L. (2012) Arab Women, Social Media, and the Arab Spring: Applying the framework of digital reflexivity to analyze gender and online activism, Joumal of International Women 's Studies, vol. 13, issue 5, pp. 31- 45.

Nikolić, M. (2010) Budućnost srpskog medijskog prostora - kreativno vs. komercijalno, Kultura: časopis za teoriju i sociologiju kulture i kulturnu politiku, br. 128, Beograd: Zavod za proučavanje kulturnog razvitka, str. 144-160.

Nikolić, M. Moć gradana - od participacije u kreiranju sadržaja do medija civilnog sektora, u Mediji civilnog dmištva kao altemativa medijskom populizmu, senzacionalizmu i lažnim vestima, postkonferencijski zbornik, priredili Gruhonjić, D. i Valić Nedeljković, D. (2019) Novi Sad: Filozofski fakultet, str. 25-39.

Nikolić, T. (2016) Rodni odnosi na altemativnoj muzičkoj sceni Srbije i regiona, Novi Sad: Zavod za ravnopravnost polova AP Vojvodine. 


\section{TATJАНА НИКОЛИЋ}

Nikolić, T. (2019a) Android apps as marketing and/or young audience development tools within cultural institutions in Serbia, izlaganje na medunarodnoj naučnoj konferenciji „Novi horizonti kulture, umetnosti i medija u digitalnom okruženju", Fakultet dramskih umetnosti, Beograd, 11-14. septembar 2019.

Nikolić, T. (20196) Umetnički projekti sa migrantkinjama - pitanja kulturnog i rodnog identiteta, Interkulturalnost: časopis za podsticanje i afirmaciju interkulturalnosti br. 18, str. 85-96.

Опачић, Б. и Субашић, Б. (2016) Културне потребе и навике граЂана Србије, Београд: Завод за проучавање културног развитка.

Veseljević Jerković, S. (2012) „Ti si superžena”: nova ženstvenost u popularnoj kulturi, Genero: časopis za feminističku teoriju i studije kulture, br. 16, Beograd: Fakultet političkih nauka, str. 117-140.

Vukićević, V. (2018) Novi mediji u mrežnoj komunikaciji, Zbomik radova Fakulteta dramskih umetnosti br. 33, Beograd: Fakultet dramskih umetnosti, str. 207-224.

Саговорнице са којима су реализовани индивидуални uнmервјуu:

Јана Адамовић, стрип ауторка и илустраторка, интервју одржан у Београду, јун 2020.

Маја Боснић, композиторка, интервју одржан путем Скајпа, јун 2020.

Јана Оршолић, графичка дизајнерка и едукаторка, интервју одржан путем Скајпа, јун 2020.

Јелена Радановић, стендап комичарка, интервју одржан у Београду, јун 2020. и јул 2020.

Јелена Милићевић, визуелна уметница, интервју одржан путем Скајпа, јул 2020.

Ана Ћурчнн, кантауторка, одговори достављени писменим путем, јул 2020 .

Јелена Палигорић Синкевић, драмска списатељнца, одговори достављени писменим путем, јул 2020.

Ивана Тодоровић, филмска редитељка, одговори достављени писменим путем, јул 2020. 
TATJAНА НИКОЛИЋ

\title{
Tatjana Nikolić
}

University of Arts in Belgrade, Faculty of Dramatic Arts -

Management and Production in Theatre, Radio and Culture, Belgrade

\section{SOCIAL ENGAGEMENT OF YOUNG FEMALE ARTISTS IN THE DIGITAL CONTEXT}

\begin{abstract}
Young women take more and more significant place in online space using all the benefits of the creative features of Internet and digital media. Even though gender inequality is possibly even more present in the online space comparing to the offline, digital environment also stands for a platform for (artistic) expression and an arena of the tension between attitudes, tastes, expressions and ideas. New generations of female authors in the local and regional digital context (could) precede, inspire and lead with their authentic critical thinking and production. This text examines if, to what extent and how young female authors use their artistic production, especially their digital platforms, for expressing social and political opinions. We were particularly investigating their understanding of feminism and gender (in)equality, as well as their experience of discrimination and sexism. The article is based on the individual interviews with selected female authors of the younger generation, through which their attitudes, values, critical artistic production, messages and narratives, as well as reactions to the global crisis and social problems were investigated. To the certain extent, the article also reflects on their content on digital communications channels (web sites, Facebook profiles and pages, Instagram profiles and other platforms for digital creativity and distribution of artistic content). This pilot research included eight female artists active in different artistic and creative fields in Serbia: visual and applied arts, music (popular and contemporary experimental), film, literature and performing arts. A particular topic that marked the social context of the first half of 2020 when the research was conducted, has been the pandemic caused by the virus covid19, as well as emergency state and isolation that came as a consequence. Additionally, context of their production, activism and life is marked by sexism existing in media, online as well as offline public space.
\end{abstract}

Key words: critical thinking, social media, arts marketing, female artistic work, young women, feminism, gender equality in culture 